\title{
Opportunities of spontaneous edible plants collected in southern Italy (Campania Region) as functional food
}

\author{
Enrica De Falco, ${ }^{1}$ Rossana Zanti, ${ }^{1}$ Antonello Senatore, ${ }^{2}$ Antonella Vitti ${ }^{1}$ \\ ${ }^{1}$ Pharmacy Department, University of Salerno, Fisciano (SA); ${ }^{2}$ S.I. Impresa (Azienda Speciale della \\ C.C.I.A.A. di Napoli), Napoli, Italy
}

\begin{abstract}
In most countries the historical-cultural heritage also refers to the foods traditionally consumed. Southern Italy maintains a strong tradition of dishes based on wild plants, considered an important dietary foundation. Despite this, the nutritional properties and nutraceutical value of some of these plants are little known and, therefore, need to be investigated. Sixteen spontaneous species, traditionally used as food plants, were collected from their natural habitat in four different areas of Campania Region, and their phenolic content and nutritional value were determined according to European model of food labelling. The species analysed resulted quite homogeneous regarding the nutritional value, as demonstrated by cluster analyses. Energy values were always low. Minerals content (especially calcium and potassium) and phenols differed among the species, the sodium-potassium ratio was almost always $<0.49$, and phenolic content was very high for Rubus ulmifolius. Many of the wild edible plants under study may be considered a good source to dietary intakes of minerals. The species examined showed contents of nutrition values and total phenols useful for preparing mixed soups or salads in order to gain a balanced nourishment. The wild species under study can become a source of new quality horticultural products due to their nutritional and nutraceutical components.
\end{abstract}

\footnotetext{
Tel.: +39.089.969750.

E-mail:avitti@unisa.it phenols.

Received for publication: 11 September 2019.

Revision received: 26 October 2019.

Accepted for publication: 8 November 2019

${ }^{\circ}$ Copyright: the Author(s), 2019

Licensee PAGEPress, Italy

Italian Journal of Agronomy 2019; 14:1540

doi:10.4081/ija.2019.1540
}

Correspondence: Antonella Vitti, Pharmacy Department, University of Salerno, via Giovanni Paolo II n.132, 84084 Fisciano (SA) Italy.

Key words: Wild plants; nutrition label; nutraceutical components; total

Conflict of interest: the authors declare no potential conflict of interest.

This article is distributed under the terms of the Creative Commons Attribution Noncommercial License (by-nc 4.0) which permits any noncommercial use, distribution, and reproduction in any medium, provided the original author(s) and source are credited.

\section{Introduction}

The utilisation of the spontaneous plants can be an effective way for encouraging history and local traditions knowledge, but also for safeguarding the agrobiodiversity. In Europe, in the past, poverty and frequent famines forced people to use the wild plants as food sources (Sánchez-Mata and Tardío, 2016), so much that Targioni-Tozzetti, in 1767, had coined the term alimurgia intending the use of wild plant as source of food to make famines less severe. Nowadays, wild plants are beginning to be appreciated in different preparation including salads, soups, herb teas, marmalades or preserved, in several parts of the world (Turner et al., 2011; Carvalho and Barata, 2017). In Italy, this recognising is mostly linked to the greater attention to the Mediterranean diet, the consumption of healthy foods, and the rediscovery of traditions. For this reason, for some spontaneous edible plants attempts at domestication (Bianco et al., 2009; Ceccanti et al., 2018) and eventual cultivation as fresh cut leafy vegetables, such as Silene vulgaris (Sánchez-Mata and Tardío, 2016; Benvenuti et al., 2017), have been made.

Campania Region (southern Italy), thanks to the presence of very variable geographical environments, is rich for different edible wild species, which are the basis of traditional dishes that generally combine a various number of plants. An ethnobotanical survey identified 69 species employed as human food and spices in an area of the National Park of Cilento and Vallo di Diano (province of Salerno) and described a typical popular local soap, named minestra terrana, prepared with 12 wild species (Di Novella et al., 2013). More recently, other authors reported the local ethnobotanical uses of wild and cultivated plants in the Agro Nocerino Sarnese (provinces of Salerno and Naples), and identified 93 taxa including Borago officinalis, that is one of the seven green vegetables used for cooking another traditional dish, the minestra maritata (Motti and Motti, 2017). Equally known is the mallone, a typical dish prepared with about 20 different spontaneous herbs (Provinces of Salerno and Avellino).

Wild plants can play a key role not only for their important gastronomic tradition, but also for increasing evidence of their therapeutic (Marrelli et al., 2015) and nutraceutical properties (Vanzani et al., 2011; Ranfa et al., 2014) induced by active components, which makes it possible to define them as functional foods (Pinela et al., 2017). Despite this, very little is known about nutritional value of some of these plants. In this context, the present study aims to evaluate if the renewed cultural interest in wild edible plants used for cooking typical dishes of local tradition can be due also to their nutritional and functional properties, by formulating the nutrition labels according to EU Regulation $1169 / 2011$, and analysing some important components of nutraceutical interest for 16 spontaneous plants collected from their natural habitat of four different areas of the Campania Region. 


\section{Materials and methods}

\section{Sample collection and preparation}

Sixteen different species of edible wild plants were collected (2015) from four diverse locations of Campania Region (Figure 1), identified because of a tradition in the use of spontaneous food plants. The species, the geographical characteristics of the areas (Table 1), the harvesting period and the portion of the plant used, based on their tradition use, are reported (Table 2).

The plants were identified, and voucher specimens have been deposited at the Herbarium of the Department of Pharmacy,
University of Salerno, Italy.

Representative samples were kept in paper bags, and transported to the laboratory, and kept under refrigerated conditions until use. On the same day, they were cleaned, so that only edible portions were used in the analysis and washed by using potable water to remove visible dirt. Then, fresh samples of each wild plant were homogenised by Grindomix (GM200).

\section{Reagent and chemicals}

All chemicals were of analytical grade and were supplied by Merck KGaA (Darmstadt, Germany).

Ultrapure water was obtained from a Milli-Q ${ }^{\circledR}$ water purification system (Millipore, Bedford, MA, USA).
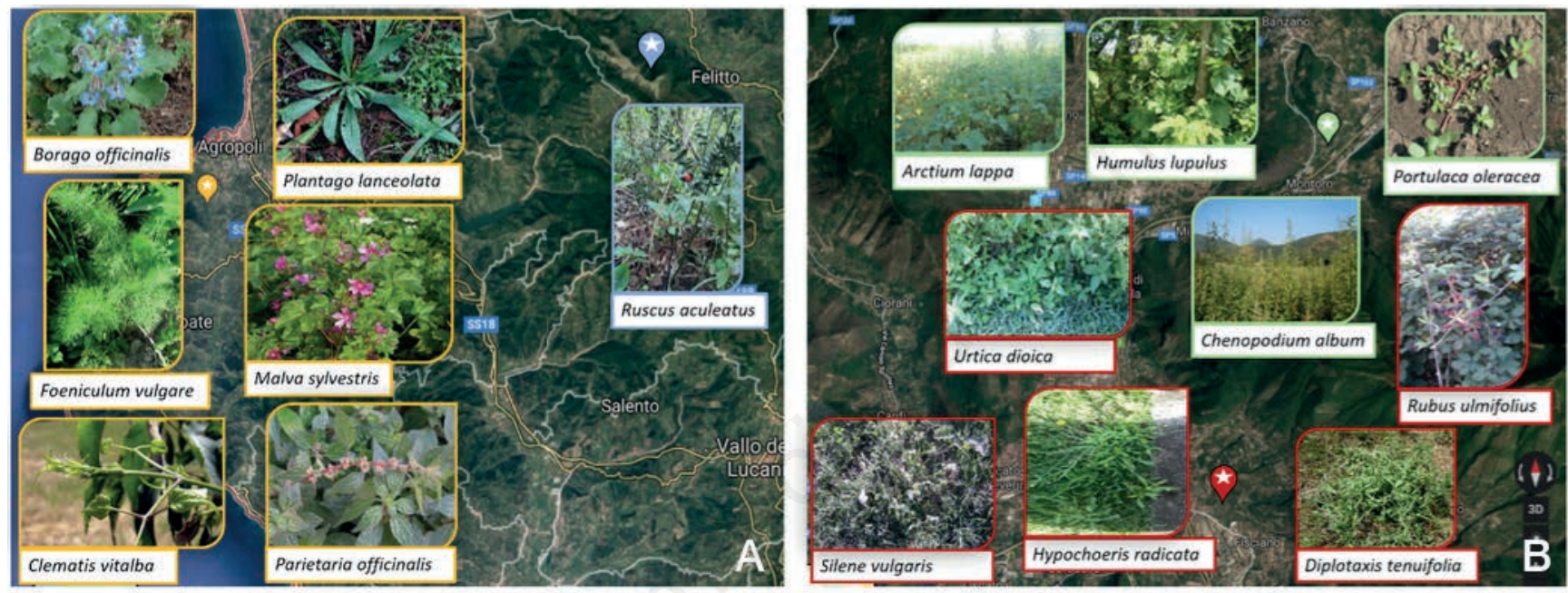

Figure 1. Collection sites of wild edible plants: Agropoli and Felitto (A); Fisciano and Montoro (B).

Table 1. Species and geographical characteristics of the collection sites.

\begin{tabular}{|c|c|c|c|c|c|c|c|}
\hline Species & Family & Location & Latitude & Longitude & $\begin{array}{l}\text { Altitude } \\
\text { (m a.s.l.) }\end{array}$ & $\begin{array}{c}\text { Average } \\
\text { temperature }\left({ }^{\circ} \mathrm{C}\right) \\
\text { 1981-1999 } \\
\text { (Ducci and } \\
\text { Tranfaglia, } \\
\text { 2008) }\end{array}$ & $\begin{array}{l}\text { Average } \\
\text { rainfall (mm) } \\
\text { 1981-1999 } \\
\text { (Ducci and } \\
\text { Tranfaglia, } \\
\text { 2008) }\end{array}$ \\
\hline $\begin{array}{l}\text { Borago officinalis } \mathrm{L} . \\
\text { Clematis vitalba } \mathrm{L} . \\
\text { Foeniculum vulgare Mil. } \\
\text { Malva sylvestris } \mathrm{L} . \\
\text { Parietaria officinalis } \mathrm{L} . \\
\text { Plantago lanceolata } \mathrm{L} .\end{array}$ & $\begin{array}{l}\text { Boraginaceae } \\
\text { Ranuncolaceae } \\
\text { Apiaceae } \\
\text { Malvaceae } \\
\text { Urticaceae } \\
\text { Plantaginaceae }\end{array}$ & Agropoli (SA) & $40^{\circ} 19^{\prime} 06^{\prime \prime} \mathrm{N}$ & $14^{\circ} 58^{\prime} 22^{\prime \prime} \mathrm{E}$ & 139 & $17-18$ & $1000-1100$ \\
\hline Ruscus aculeatus L. & Liliaceae & Felitto (SA) & $40^{\circ} 22^{\prime} 08^{\prime \prime} \mathrm{N}$ & $15^{\circ} 14^{\prime} 48^{\prime \prime} \mathrm{E}$ & 258 & $16-17$ & $1000-1100$ \\
\hline $\begin{array}{l}\text { Diplotaxis tenuifolia } \mathrm{L} . \mathrm{DC} \\
\text { Hypochoeris radicata } \mathrm{L} . \\
\text { Silene vulgaris (Moench) Garcke } \\
\text { Rubus ulmifolius Schott. } \\
\text { Urtica dioica L. }\end{array}$ & $\begin{array}{l}\text { Brassicaceae } \\
\text { Asteraceae } \\
\text { Caryophyllaceae } \\
\text { Rosaceae } \\
\text { Urticaceae }\end{array}$ & Fisciano (SA) & $40^{\circ} 46^{\prime} 25^{\prime \prime} \mathrm{N}$ & $14^{\circ} 47^{\prime} 09^{\prime \prime} \mathrm{E}$ & 244 & $15-16$ & $1100-1200$ \\
\hline $\begin{array}{l}\text { Arctium lappa } \mathrm{L} . \\
\text { Chenopodium album } \mathrm{L} . \\
\text { Humulus lupulus } \mathrm{L} . \\
\text { Portulaca oleracea } \mathrm{L} .\end{array}$ & $\begin{array}{l}\text { Asteraceae } \\
\text { Chenopodiaceae } \\
\text { Cannabaceae } \\
\text { Portulacaceae }\end{array}$ & Montoro (AV) & $40^{\circ} 50^{\prime} 07^{\prime \prime} \mathrm{N}$ & $14^{\circ} 46^{\prime} 04^{\prime \prime} \mathrm{E}$ & 185 & $13-14$ & $1200-1300$ \\
\hline
\end{tabular}


Internal standard for inductively coupled plasma mass spectrometry were obtained from LGC Standards (Teddington, Middlesex, UK); hydrogen $\left(99.9999 \% \mathrm{H}_{2}\right)$ was obtained by the Hydrogen Generator PGH2-300, VICI AG International, Schenkon, Switzerland; helium $(99.9999 \% \mathrm{He})$ was purchased by SALDOGAS Srl, Italia, Naples, Italy.

\section{Determination of the nutritional label}

For each sample, three replicates of the edible fresh parts of the plants were analysed. All determinations were performed according to AOAC procedures (1995).

Nitrogen content of $2 \mathrm{~g}$ of plant samples was estimated by Kjeldahl method (Digester K-438, Distiller B-324, BUCHI Italia s.r.l Cornaredo, Italy) and crude protein content was calculated as $\mathrm{N} \times 6.25$.

The determination of the total lipids was obtained by extracting $10 \mathrm{~g}$ of plant samples with hexane, using the Soxhlet extraction device (VWR International PBI s.r.l., Milan, Italy) (AOAC, 1995).

The moisture content was determined by weight loss of $2 \mathrm{~g}$ of plant sample at $105^{\circ} \mathrm{C}$ in an ISCO oven, model NSV 9035 (ISCO, Milan, Italy) until a constant weight was reached (AOAC, 1995).

Ash content was determined by incineration of $10 \mathrm{~g}$ of plant sample in a muffle (model K1251F, W.C. Heraeus GmbH, Hanau, Germany), at $550^{\circ} \mathrm{C}$ for $4 \mathrm{~h}$ (AOAC, 1995).

Total amount of carbohydrates was calculated as a difference to 100 of water+ash+total protein+total fat+raw fiber.

Glucose and fructose were determined by the colorimetricenzymatic method by using the automated multi-parametric Analyser Y15 SinaTech together with the relative analysis kits (BioSystems, S.A., Barcelona, Spain), according to the manufacturer's instructions, starting from $10 \mathrm{~g}$ of each plant sample.

The dried residue remaining after digestion of $5 \mathrm{~g}$ of plant sample with $0.125 \mathrm{~N} \mathrm{H}_{2} \mathrm{SO}_{4}$ and $0.125 \mathrm{~N} \mathrm{NaOH}$ solutions, until boiling, for 30 and $60 \mathrm{~min}$, respectively, was used to determine raw fiber content. The Weende method (AOAC 1995) was executed by using the Velp Scientifica ${ }^{\mathrm{TM}}$ FIWE3 Model Raw Fiber Extractor (Thermo Fisher Scientific Inc., Sweden), according to the manufacturer's instructions.

Energy value was calculated as follow: $\mathrm{kcal}=4 \times(\mathrm{g}$ protein $+\mathrm{g}$ carbohydrate $)+9 \times($ g lipid $)+2 \times(\mathrm{g}$ fiber $) ; \mathrm{kj}=17 \times(\mathrm{g}$ protein $+\mathrm{g}$ carbohydrate $)+37 \times($ g lipid $)+8 \times($ g fiber $)$ (Regulation 1169/2011).

Salt equivalent content was calculated as sodium $(\mathrm{g}) \times 2.5$ (Regulation 1169/2011).

\section{Determination of fatty acids}

Fatty acids were determined by gas chromatography with flame ionisation detection (GC-FID), starting from total lipids obtained by Soxhlet extraction. The trans-esterification procedure was carried out with potassium hydroxide in methanol $(\mathrm{KOH}-$ $\left.\mathrm{CH}_{3} \mathrm{OH}\right) 2 \mathrm{~N}(11.2 \mathrm{~g}$ in $100 \mathrm{~mL})$, by shaking in vortex for $5 \mathrm{~min}$ and left to stand for other $5 \mathrm{~min}$. The upper phase containing the fatty acid methyl esters (FAME) was recovered (Regulation 2568/91; Regulation 2015/1833).

The fatty acid profile was analysed with a gas chromatograph GC-2010 Plus (Shimadzu Italia S.r.l., Milan, Italy) equipped with a split injector, a flame ionisation detector (FID) and a capillary column $(30 \mathrm{~m} \times 0.25 \mathrm{~mm}$ ID $\times 0.25 \mu \mathrm{m} \mathrm{df})$, model Zebron ZBWAX (Phenomenex, Castel Maggiore, Italy). For each analysis 1 $\mu \mathrm{L}$ of the sample was injected in the column. The oven temperature program was the following: $170^{\circ} \mathrm{C}$ for $2 \mathrm{~min} ; 2^{\circ} \mathrm{C} \mathrm{min}-1$ until to $185^{\circ} \mathrm{C}$ and held for $10 \mathrm{~min} ; 1^{\circ} \mathrm{C} \mathrm{min}-1$ until to $190{ }^{\circ} \mathrm{C}$ and held for $12 \mathrm{~min} ; 10^{\circ} \mathrm{C} \mathrm{m^{-1 }}$ until to $240^{\circ} \mathrm{C}$ and held for $5 \mathrm{~min}$. Helium was used as carrier to $40 \mathrm{~cm} \mathrm{sec}^{-1}$, and the split injection (1:10) was carried out at $300^{\circ} \mathrm{C}$. The content of every component has been expressed as percentage by mass of methyl esters (determining the percentage represented by the area of the corresponding peak relative to the sum of the areas of all the peaks, and then converting the percentage of methyl ester in that of the corresponding acid fat multiplying by an appropriate corrective factor).

\section{Determination of minerals}

Ash samples were digested in a $1 \%$ nitric acid $\left(\mathrm{HNO}_{3}\right)$ solution by using a microwave digestion unit, model MARS $6^{\mathrm{TM}}$ (CEM SRL, Cologno al Serio, Italy).

The content of minerals was determined by inductively coupled plasma mass spectrometry (ICP-MS) with quadrupole detector, model Bruker 820-MS (Bruker Daltonics, Macerata, Italy).

The operating conditions were the following: Plasma gas flow,

Table 2. Harvesting period and part of the plants used.

\begin{tabular}{|c|c|c|}
\hline Species & Harvesting & Plant parts \\
\hline $\begin{array}{l}\text { Borago officinalis L. } \\
\text { Clematis vitalba L. } \\
\text { Foeniculum vulgare Mil. } \\
\text { Malva sylvestris L. } \\
\text { Parietaria officinalis L. } \\
\text { Plantago lanceolata L. } \\
\text { Ruscus aculeatus L. }\end{array}$ & First fifteen of May & $\begin{array}{l}\text { Young leaves } \\
\text { Vegetative shoots apices } \\
\text { Young leaves } \\
\text { Young leaves } \\
\text { Young Leaves } \\
\text { Young leaves } \\
\text { Turions (new shoots) }\end{array}$ \\
\hline $\begin{array}{l}\text { Arctium lappa L. } \\
\text { Hypochoeris radicata L. } \\
\text { Chenopodium album L. } \\
\text { Humulus lupulus } \mathrm{L} . \\
\text { Portulaca oleracea } \mathrm{L} .\end{array}$ & First fifteen of August & $\begin{array}{l}\text { Young Leaves } \\
\text { Young leaves } \\
\text { Young Leaves } \\
\text { Vegetative shoots apices } \\
\text { Young leaves }\end{array}$ \\
\hline $\begin{array}{l}\text { Diplotaxis tenuifolia L. DC } \\
\text { Rubus ulmifolius Schott. } \\
\text { Silene vulgaris (Moench) Garcke } \\
\text { Urtica dioica L. }\end{array}$ & Last fifteen of August & $\begin{array}{l}\text { Young leaves } \\
\text { Vegetative shoots apices } \\
\text { Ripe fruits } \\
\text { Young leaves } \\
\text { Young leaves }\end{array}$ \\
\hline
\end{tabular}


$18 \mathrm{~L} \mathrm{~min}^{-1}$; Auxiliary gas flow, $1.8 \mathrm{~L} \mathrm{~min}^{-1}$; Nebuliser gas flow, $0.98 \mathrm{~L} \mathrm{~min}^{-1}$; Sheat gas flow, $0.14 \mathrm{~L} \mathrm{~min}^{-1}$; collision-reaction interface (CRI) skimmer gas Hydrogen, $50 \mathrm{~mL} \mathrm{~min}{ }^{-1}$; CRI sample gas Helium, $10 \mathrm{~mL} \mathrm{~min}{ }^{-1}$; ICP RF power, $1.4 \mathrm{~kW}$; sample introduction pump rate, $4 \mathrm{rpm}$; stabilisation time, $20 \mathrm{sec} ; 1^{\text {st }}$ extraction lens voltage, - $40 \mathrm{~V}$; $2^{\text {nd }}$ extraction lens voltage, $-166 \mathrm{~V}$; $3^{\text {th }}$ extraction lens voltage, - $234 \mathrm{~V}$; corner lens voltage, - $208 \mathrm{~V}$; mirror lens left voltage, $29 \mathrm{~V}$; mirror lens right voltage, $26 \mathrm{~V}$; mirror lens bottom voltage, $30 \mathrm{~V}$; quadrupole scan dwell time, 10,000 $\mu \mathrm{s}$; quadrupole scans/replicate, 10; quadrupole replicates/sample, 5.

Blanks (only $\mathrm{HNO}_{3}$ and $\mathrm{H}_{2} \mathrm{O}$ ) and nine standard stock solution of $0.5,1,2.5,5,10,25,50,100,250 \mathrm{ppb}$ were analysed for reference purposes, in order to cover the entire analyte concentration range in the samples to be analysed. The results were expressed as $\mu \mathrm{g}$ or $\mathrm{mg}$ of mineral $100 \mathrm{~g}^{-1}$ of plant fresh weight.

\section{Phenolic determination}

Five $\mathrm{g}$ of fresh plant sample were added and stirred with $40 \mathrm{~mL}$ of methanol $\left(\mathrm{CH}_{3} \mathrm{OH}\right)$. The sample was extracted in an ultrasonic bath (SONICA; SOLTEC ${ }^{\circledR}$, Milan, Italy) at $30^{\circ} \mathrm{C}$ for $30 \mathrm{~min}$ and filtered through Whatman filter paper. This procedure was repeated for three times. To an aliquot of $0.5 \mathrm{~mL}$ of the extract, distilled ultrapure water was added to a final volume of $10 \mathrm{~mL}$ and then mixed with $1 \mathrm{~mL}$ Folin-Ciocalteu reagent; after $3 \mathrm{~min}, 2 \mathrm{~mL}$ of a $20 \%$ sodium carbonate $\left(\mathrm{Na}_{2} \mathrm{CO} 3\right)$ solution was added and then diluted with distilled ultrapure water to a final volume of $50 \mathrm{~mL}$. The tubes were allowed to stand for $120 \mathrm{~min}$ for colour development. Absorbance was then measured at $725 \mathrm{~nm}$ by a spectrophotometer (UV-1800; Shimadzu Italia S.r.l., Milan, Italy). Caffeic acid was used to calculate the standard curve $\left(0.00-8.0 \mathrm{mg} \mathrm{L}^{-1}\right.$; y $\left.=0.12285 \mathrm{x}+0.00000 \mathrm{y} ; \mathrm{R}^{2}=0.99398\right)$ and the results were expressed as mg of caffeic acid equivalents (CAEs) $100 \mathrm{~g}^{-1}$ of plant fresh weight.

\section{Statistical analysis}

Following the Shapiro-Wilk and Bartlett's tests for normality and common variance of the experimental error, respectively, significant differences among wild plants (for all data of nutrition labels, unsaturated fatty acids, minerals content and total phenols) were determined by one-way ANOVA, according to a completely randomised design with three replicates. Comparison among means was determined by using Tukey post-hoc test $(\mathrm{P} \leq 0.05)$. All analyses were performed by MSTAT-C software package (Michigan State University, MI, USA).

Data deriving from nutrition labels, total phenols and minerals content were subjected to cluster analysis, performed by using the Multivariate exploratory techniques, selecting a complete linkage, Euclidean distances, and a tree diagram (Statistica, version 10, StatSoft Inc., Tulsa OK Oklahoma, United States).

\section{Results and discussion}

\section{Nutrition composition}

The nutritional composition of the wild species, always expressed per $100 \mathrm{~g}^{-1}$ of fresh weight (FW), is shown in Table 3 . All plants were characterised by low energy values, less than 100 kcal, except for Arctium lappa and Humulus lupulus, which are slightly higher (107.21 and $105.37 \mathrm{kcal}$, respectively), although significantly different from each other.
Total fat showed very low values, except for Arctium lappa, which had significantly higher values (1.35 g $\left.100 \mathrm{~g}^{-1} \mathrm{FW}\right)$, also concerning the saturated and monounsaturated fatty acids. Instead, Chenopodium album was the wild plant with a significant higher

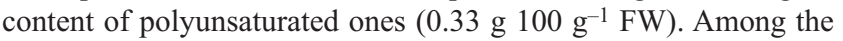
16 plants, 11 showed higher content of polyunsaturated fatty acids (PUFAs) than saturated ones. This is important considering that PUFAs play a crucial role in reducing the risk for coronary heart disease and strengthening the immune system (Simopoulos, 2004; Harris et al., 2009; Sánchez-Mata and Tardío, 2016). Moreover, plants revealed less variability at regard to monounsaturated fatty acids, except for the above-mentioned Arctium lappa and also for Plantago lanceolata, that showed the highest values.

For all wild plants here considered, the values of total carbohydrate ranged from $2.01 \mathrm{~g}$ (Silene vulgaris) to $18.04 \mathrm{~g}$ (Humulus lupulus), with a wide variability among all plants. They are comparable to the literature data for the species Chenopodium album

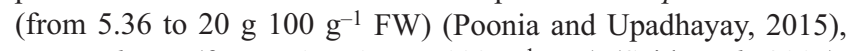

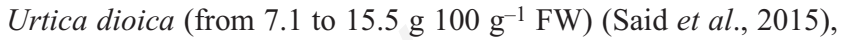

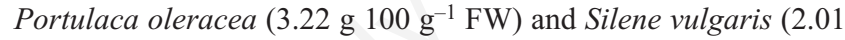
g $100 \mathrm{~g}^{-1}$ FW) (Pinela et al., 2017). Furthermore, data obtained from this study were compared to those of some cultivated species used for the preparation of salads and/or soups, such as chard (Beta vulgaris L.), chicory (Cichorium intybus L.), lettuce (Lactuca sativa L.) and spinach (Spinacia oleracea L.) of INRAN Databank (Carnovale and Marletta, 2013). The carbohydrate contents that we found in the wild plants were quite high respect to the data reported

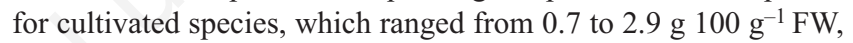
thus conferring a good culinary value to these plant, as related to their high levels of sugars (Pinela et al., 2017). In particular, within the carbohydrates fraction, the monosaccharides glucose and fructose were examined, the first being the most abundant in almost all plants, except for Plantago lanceolata and Rubus ulmifolius fruits, where the fructose content prevailed.

As regards to crude fibers, Diplotaxis tenuifolia showed the lowest content $(0.95 \mathrm{~g})$, while Rubus ulmifolius the highest one (6.26 and $7.15 \mathrm{~g}$ in the apices and fruits, respectively), with a wide variability among all plants, except for Clematis vitalba and Urtica dioica, having the same value. On average, all values were similar

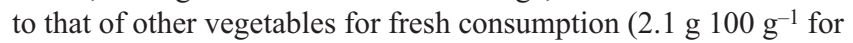
spinach, raw), indicated by Dhingra et al. (2012).

The mean protein content ranged from 0.91 (Rubus ulmifolius

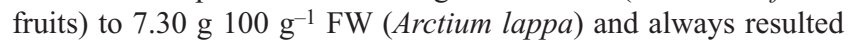
almost similar to the values of the literature data for Chenopodium album (3.7-5.0 g $100 \mathrm{~g}^{-1} \mathrm{FW}$ ) (Poonia and Upadhayay 2015), Diplotaxis tenuifolia, Foeniculum vulgare and Portulaca oleracea

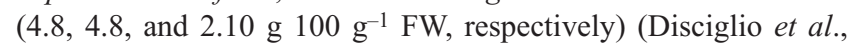
2017), Plantago lanceolata (2.12 g $100 \mathrm{~g}^{-1} \mathrm{FW}$ ) (Guil-Guerrero 2001), Silene vulgaris (3.10 g $100 \mathrm{~g} \mathrm{~g}^{-1} \mathrm{FW}$ ) (Pinela et al., 2017), and Urtica dioica (4.3-8.9 g $100 \mathrm{~g}^{-1}$ FW) (Said et al. 2015). Instead, the values of protein content resulted higher to that of Borago officinalis (1.20-1.90 g $100 \mathrm{~g}^{-1} \mathrm{FW}$ ) (Disciglio et al., 2017; Pinela et al., 2017), Humulus lupulus and Malva sylvestris (4.30

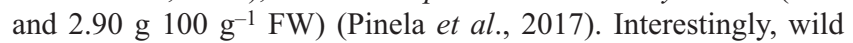
species under study showed less variability among all plants, and appeared to have almost always high protein levels with respect to the above-mentioned vegetables chard, chicory, lettuce and

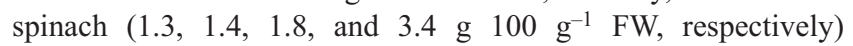
(Carnovale and Marletta, 2013). Thus, some selected plants, such as Clematis vitalba, Urtica dioica, and mainly Arctium lappa, can be considered a fairly good source of proteins.

Arctium lappa showed the lowest water content (68.63\%), and Hypochoeris radicata the highest one (90.83). We found a wide 


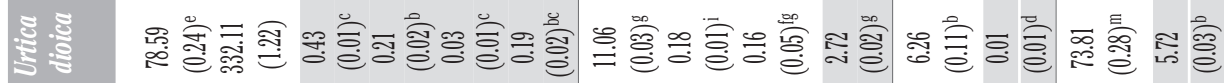

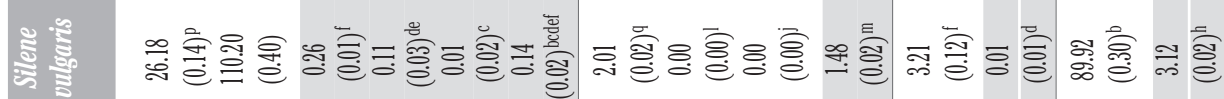

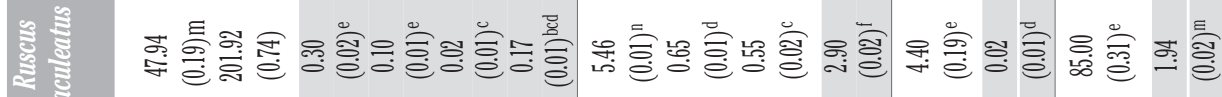

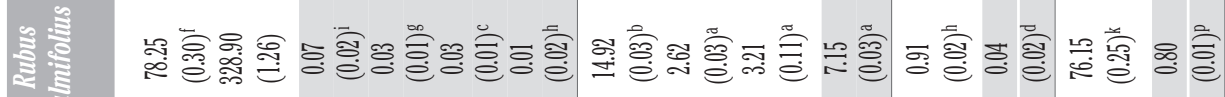

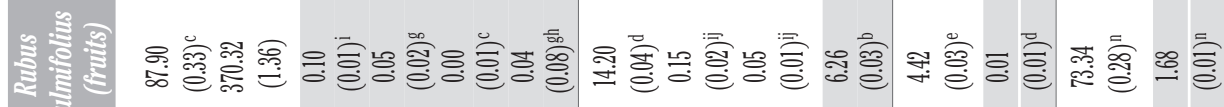

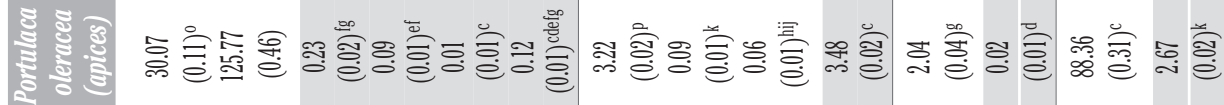

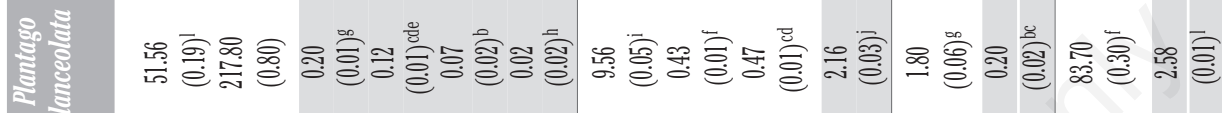

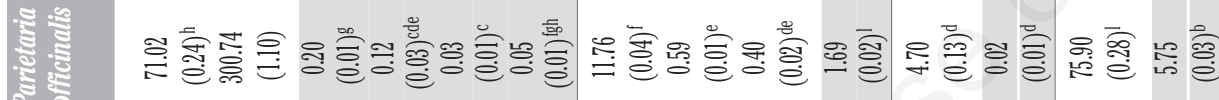

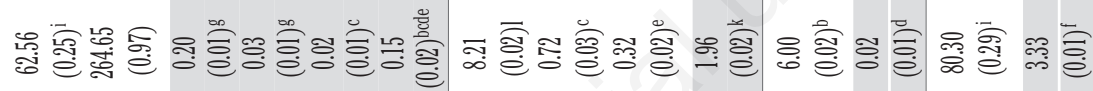

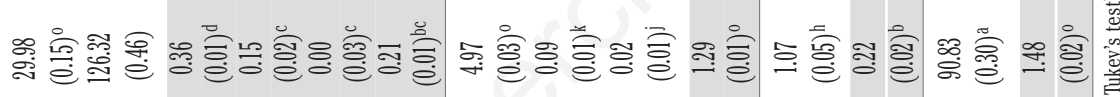

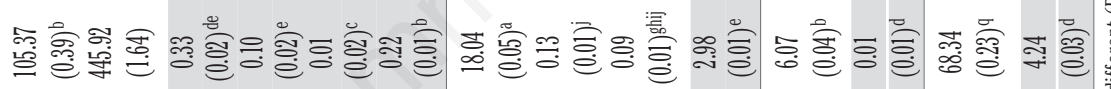

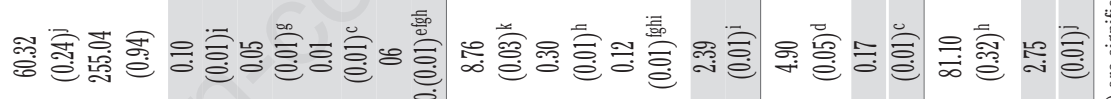

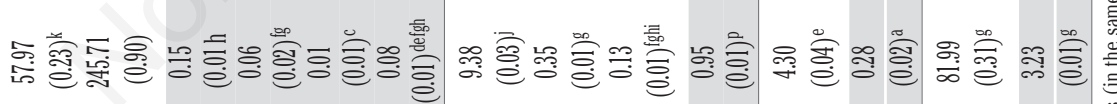

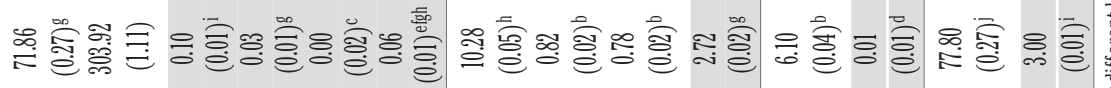

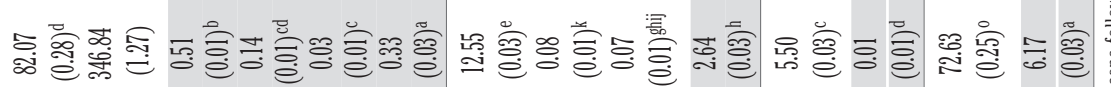

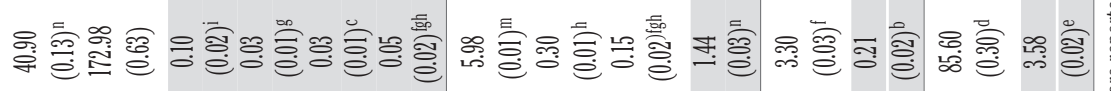

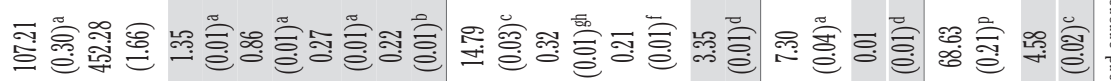

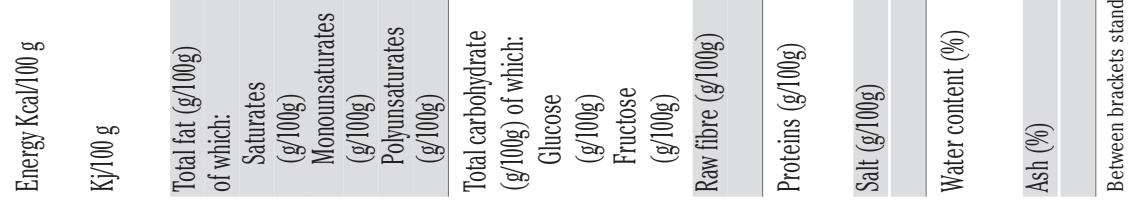


variability of values and, on average, lower water contents if compared to those of the cultivated species reported by INRAN Databank (from $89.30 \%$ of chard to $94.30 \%$ of lettuce) (Carnovale and Marletta, 2013), probably because they are spontaneous and, therefore, not irrigated species. In fact, with respect to other wild species, the values are comparable, for example, in Plantago lanceolata (86.6\%) (Guil-Guerrero 2001) and Borago officinalis $(86.90 \%)$ (Pinela et al., 2017) or higher, such as for Foeniculum vulgare (76.40\%) (Pinela et al., 2017) and Rubus ulmifolius fruits (70.77\%) (Ruiz-Rodríguez et al., 2014).

The total amount of minerals (\% of ash content in Table 3) revealed values ranging from $0.80 \%$ (fruits of Rubus ulmifolius) to $6.17 \%$ of Chenopodium album. In general, ash content is similar for the species collected in the same geographical area of Agropoli (about 2.58-3.58\%) (Table 1), except for Parietaria officinalis, with a percentage of $5.75 \%$, probably linked to its high calcium content. On the other hands, this last plant showed a value identical to that of Urtica dioica, which was collected in a different area, but belongs to the same family Urticaceae.

\section{Fatty acids profile}

As showed in Table 4, linolenic (omega-3 and -6) and linoleic (omega-6) acids were almost always among the 3 most abundant unsaturated fatty acids, being Malva sylvestris and Silene vulgaris the species with the highest percentage of linolenic and linoleic acids (68.89\% and $41.26 \%$, respectively). Ruscus aculeatus (53.97\%), Chenopodium album (46.90\%) and Humulus lupulus $(43.80 \%)$ resulted rich of linolenic acids, too. Instead, Urtica dioica, Foeniculum vulgare and Clematis vitalba showed high percentage $(33.19 \%, 32.01 \%$ and $28.91 \%$, respectively) of linoleic acids. These results are noteworthy, considering the importance to consume food rich of omega-3 and omega- 6 fatty acids for the prevention of certain diseases (Simopoulos, 2004; Harris et al., 2009). Moreover, they confirm the usefulness of combining different plants for the preparation of salads in order to gain the best supply of omega- 3 and -6 unsaturated fatty acids.

\section{Mineral composition}

Minerals are essential nutrients for the correct functioning of the human body and, currently, the interest for their evaluation in the vegetables is remarkable, especially for consumers like vegans, precisely because of their nutritional properties and beneficial health effects (Gupta and Gupta, 2014). Mineral contents were reported in Table 5. For the macro elements, calcium values ranged from the lowest of Ruscus aculeatus (18.46 mg $100 \mathrm{~g}^{-1} \mathrm{FW}$ ) to the highest of Parietaria officinalis (617.31 mg $100 \mathrm{~g}^{-1} \mathrm{FW}$ ). Furthermore, they exhibited high variability among all plants, apart for Chenopodium album and Foeniculum vulgare.

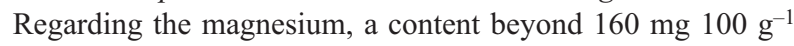
FW was exhibited by several plants (Portulaca oleracea, Arctium lappa, Chenopodium album, and Rubus ulmifolius apices).

The range of potassium was between $108.53 \mathrm{mg}$ of Clematis vitalba and $1087.84 \mathrm{mg} 100 \mathrm{~g}^{-1} \mathrm{FW}$ of Chenopodium album, the first one presenting the same significance of those of other seven wild plants.

Sodium content ranged from $2.26 \mathrm{mg}$ (Urtica dioica) to 112.13 mg $100 \mathrm{~g}^{-1} \mathrm{FW}$ (Diplotaxis tenuifolia) and showed little variability. Sodium content deserves an important consideration because it is the key element for determining the salt content, as previously explained in the methods section. For all wild plants, we found that the content of this element (Table 5) and, consequently, of salt (Table 3 ) were always definitely below the limits recommended by

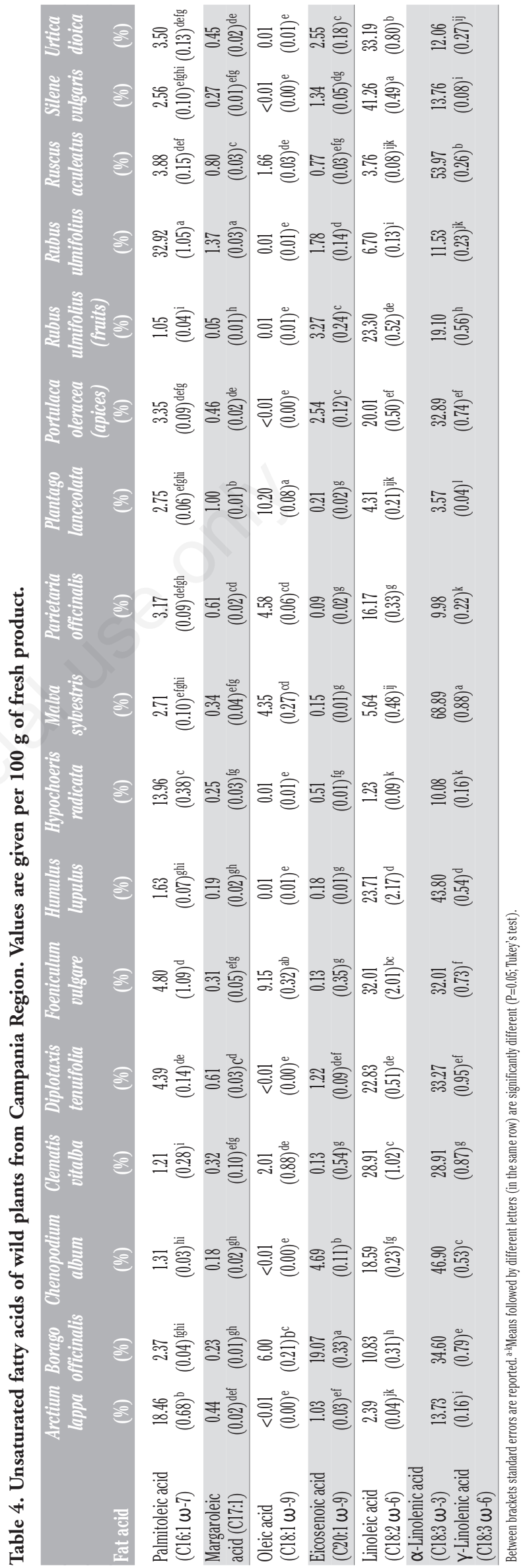




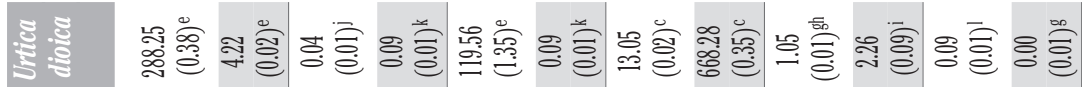

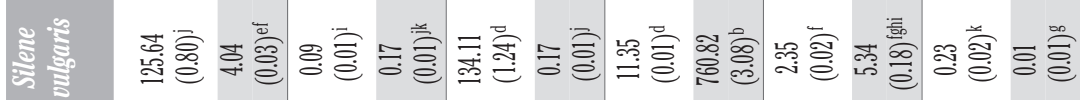

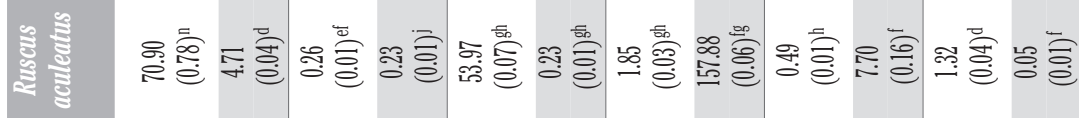

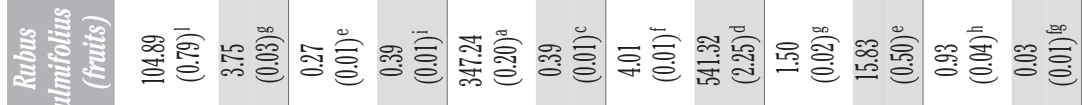

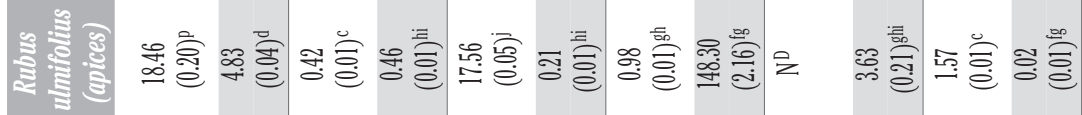

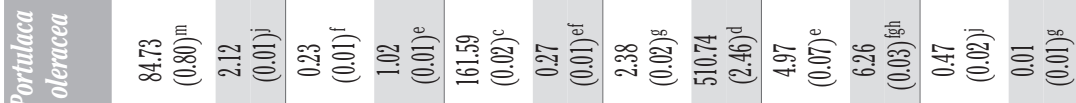

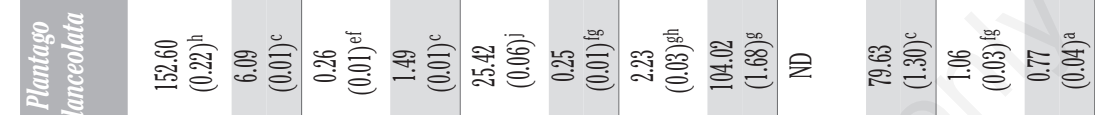

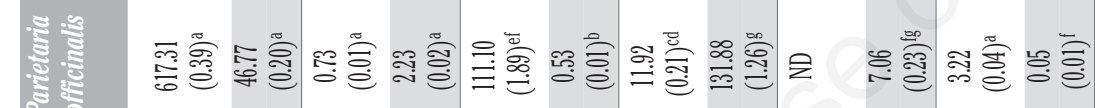

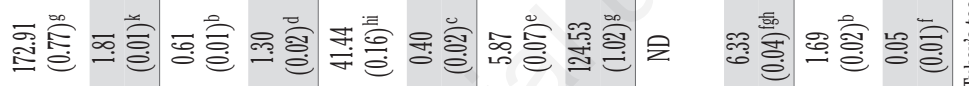

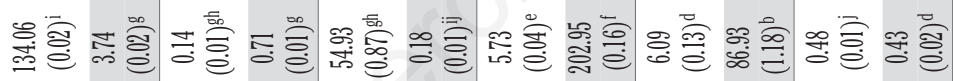

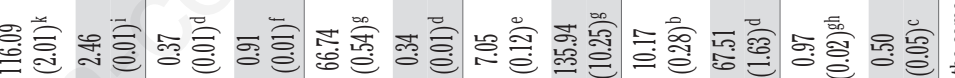

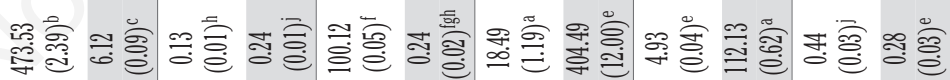

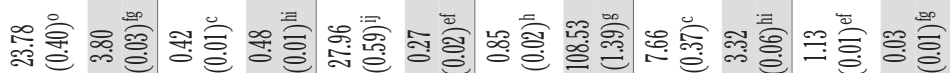

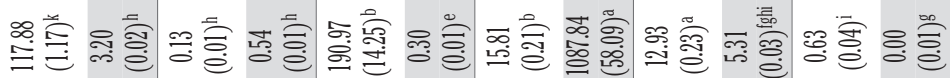

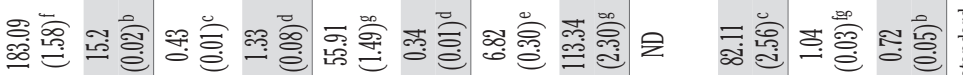

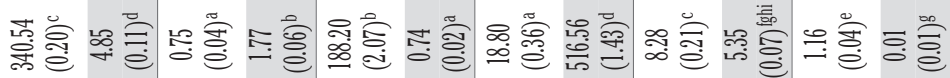

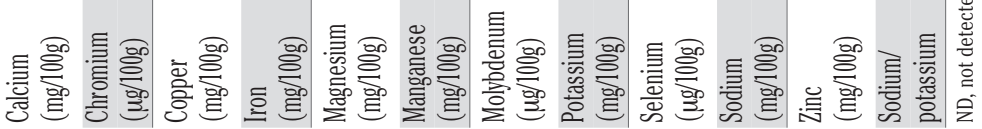


the World Health Organisation (WHO) in 2016, that indicates values $<2 \mathrm{~g}$ and $<5 \mathrm{~g}$, respectively. Nevertheless, the sodium-potassium ratio was always in favour of potassium with values slightly higher than 0.49 only for Borago officinalis, Foeniculum vulgare, and Plantago lanceolata. These results agree with the WHO recommendations according to which sodium-potassium ratio would be $<0.49$ for healthy people (Bailey et al., 2016) for reducing the risk of cardiovascular disease mortality (Drewnowski et al., 2012).

Spinach is usually considered as the vegetable source of the iron, with a content of $2.9 \mathrm{mg} 100 \mathrm{~g}^{-1} \mathrm{FW}$ (Carnovale and Marletta, 2013); we found in Parietaria officinalis an iron content very similar to that of spinach, equal to $2.23 \mathrm{mg} 100 \mathrm{~g}^{-1} \mathrm{FW}$.

It is interesting to highlight that Arctium lappa showed the highest values of copper (together with Parietaria officinalis), manganese, and molybdenum (together with Diplotaxis tenuifolia) content, and exhibited the third highest value of selenium (together with Clematis vitalba). Hence, this plant results noteworthy, also considering its high protein content above-mentioned.

Wild plants commonly are not known as good sources for zinc because its levels typically are below $1 \mathrm{mg} 100 \mathrm{~g}^{-1} \mathrm{FW}$ (Renna et al., 2015). On the contrary, many plants analysed in this study exhibited a content of zinc higher than this value, above all Parietaria officinalis with $3.22 \mathrm{mg} 100 \mathrm{~g}^{-1} \mathrm{FW}$.

Finally, for all wild plants, the values of cadmium and lead were always lower than the levels established for vegetables by the European Union (Regulation 488/2014; Regulation 2015/1005) (data not reported).

These results confirmed that many wild edible plants may be considered a good source to dietary intakes of mineral elements (Sánchez-Mata and Tardío, 2016; Renna, 2017), also by comparing our data with the nutrient reference value (NRV) for daily reference intake (DRI) in the adults for some daily macro-mineral (potassium, calcium and magnesium) and micro-, trace-elements (copper, iron, manganese, zinc, chromium, molybdenum, and selenium) established by the European Union (Regulation 1169/2011). In fact, the high contents of calcium that we found in Diplotaxis tenuifolia and Parietaria officinalis (Table 5) would be able to supply 59 and $77 \%$, respectively, of DRI $(800 \mathrm{mg})$ with a portion of $100 \mathrm{~g} \mathrm{FW}$. Concerning the magnesium, 93\% of the recommended DRI (375 mg), could be satisfied by $100 \mathrm{~g}$ of Rubus ulmifolius apices, which showed a content of this mineral of $347.24 \mathrm{mg}$. About the potassium, we found a content of $1087.84 \mathrm{mg}$ for Chenopodium album, that represent $54 \%$ of the DRI $(2000 \mathrm{mg})$ for $100 \mathrm{~g}$, allowing us to count this plant as a fairly good supplier of potassium. As previously mentioned, Arctium lappa is rich in copper, manganese, and molybdenum, being able to supply 75,37 , and $37.6 \%$ of DRI with the consumption of $100 \mathrm{~g} \mathrm{FW}$.

\section{Total phenols}

Total phenolic content ranged from $18.7 \mathrm{mg}_{100 \mathrm{~g}^{-1} \mathrm{FW}}$

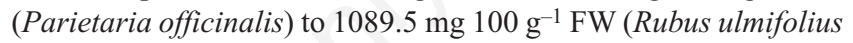
apices) (Figure 2).

It was reported that plants belonging to the Lamiaceae and Asteraceae families are richer in total phenolic content and have a stronger antioxidant potential than those of the Apiaceae family, confirming that phenolic compounds could be important contributors for the antioxidant capacity of vegetables (Sánchez-Mata and Tardío, 2016; Fernandes et al., 2017; Ulewicz-Magulska and Wesolowski, 2018).

Of interest are the results related to the total phenolic content

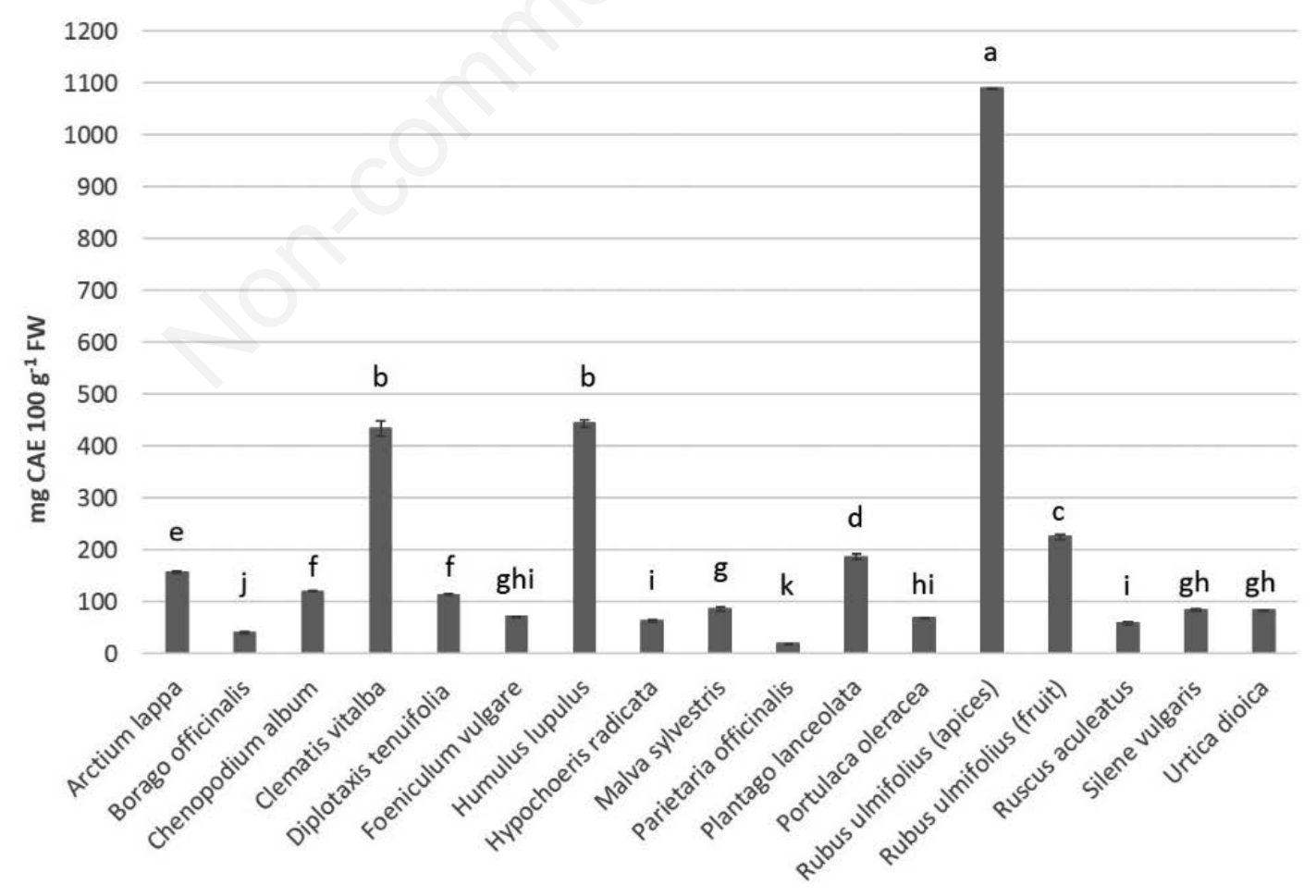

Figure 2. Total phenolic content in the wild plants from Campania Region, expressed as mg of caffeic acid equivalents (CAE) $100 \mathrm{~g}^{-1}$ fresh weight $(\mathrm{FW})$. Data are means \pm standard errors. Means followed by different letters are significantly different $(P=0.05$; Tukey's test). 
of Rubus ulmifolius for both fruits (225.08 mg $\left.100 \mathrm{~g}^{-1} \mathrm{FW}\right)$ and the above-mentioned vegetative shoots apices. The fruits of wild Rubus ulmifolius were considered valuable sources of bioactive compounds with antioxidant activity with an amount of total phe-

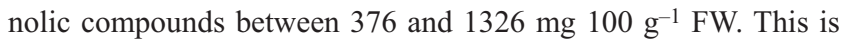
because those values are in the highest range or even above those reported for the majority of berries, that ranged from 192 to 929 mg $100 \mathrm{~g}^{-1}$ FW (Ruiz-Rodríguez et al., 2014). In our case, total phenolic content of Rubus ulmifolius fruits falls in this last range, too and that of vegetative shoots apices are above it. This finding, in addition to the remarkable fiber amounts found both in the apices and in the fruits, as reported before, makes this plant worthy of note.

\section{Cluster analysis}

The dendrogram obtained by processing data from nutritional labels showed that the distance between all wild plants was relatively small although it was possible to observe small groupings (Figure 3A).

Hence, we can consider the species analysed quite homogeneous regarding the nutritional value. When mineral content was considered (Figure 3B), the general linkage distances were much greater with respect to those previously examined, thus highlight- ing greater differences between species. In the cluster diagram, three main groups resulted, the first being to the left of Chenopodium album and characterised by high content of potassium. Another group was identified to the right of Parietaria officinalis, with high content of calcium. The central group, going from Ruscus aculeatus to Borago officinalis, had increasing calcium content and decreasing potassium content. Remarkably, Parietaria officinalis and Chenopodium album, which resulted isolated, exhibited the highest content of calcium and potassium, respectively. The dendrogram obtained by adding the total phenols content (Figure 3C) highlighted a general linkage distance much greater compared to the previous ones. In this case, the phenols and potassium resulted determinant for distances. In particular, Rubus ulmifolius (apices) was isolated in a clear way compared to the others due to the very high content of total phenols. The following two small grouping (Humulus lupulus and Clematis vitalba; Rubus ulmifolius (fruits), and Plantago lanceolata) were also characterised by high levels of total phenols, although lower than those of Rubus ulmifolius apices.

The central group, between Parietaria officinalis and Borago officinalis, was characterised by low content of both phenols and potassium, while the group going from Urtica dioica to Arctium lappa showed intermediate contents of phenols and potassium.
A

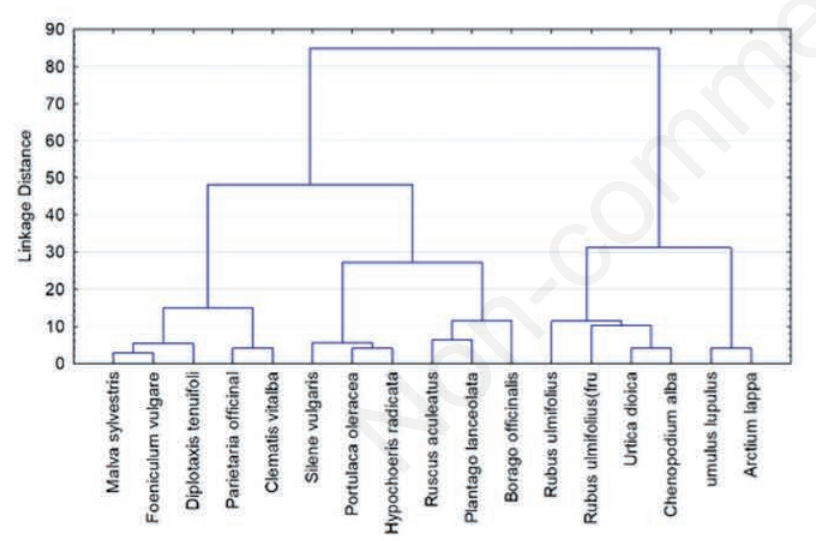

C

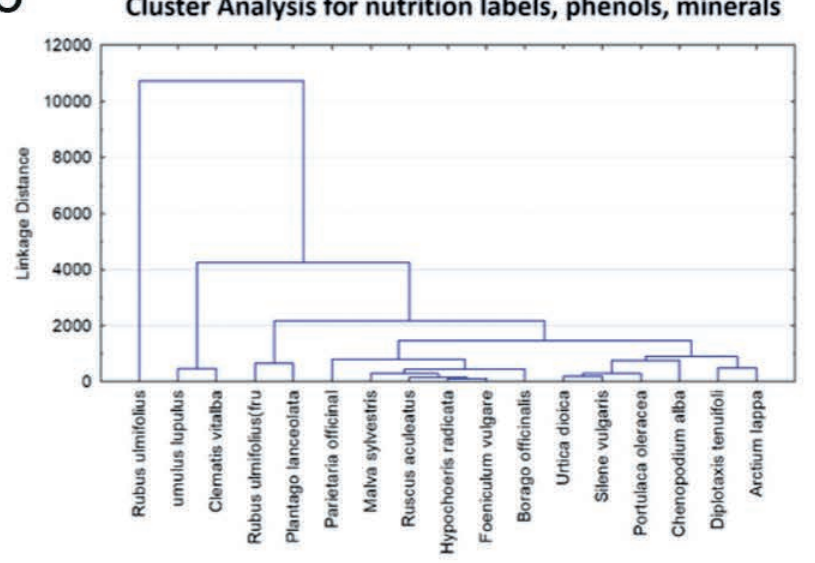

B Cluster Analysis for minerals

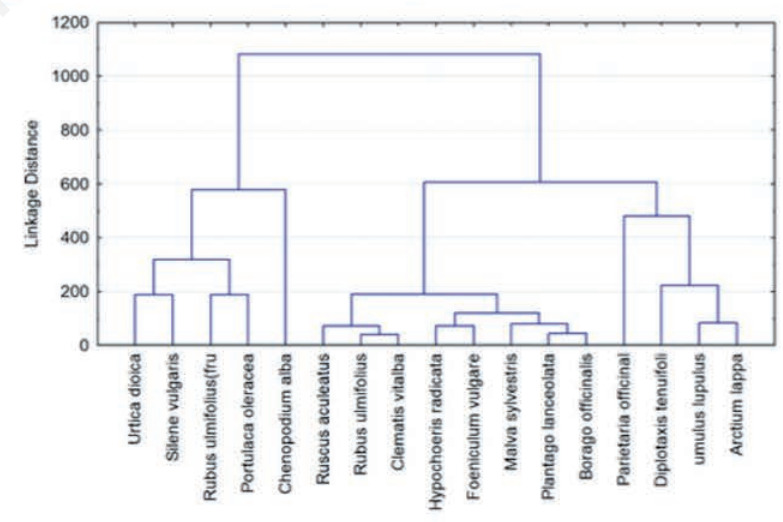

Figure 3. Tree diagram referred to the Euclidean distances among wild plants from Campania Region for: nutrition label (A); minerals (B); nutrition label, phenols, minerals (C) data. 


\section{Conclusions}

Based on results of this study, it was possible to gain new information for wild edible plants, especially Arctium lappa, Clematis vitalba, Parietaria officinalis, Ruscus aculeatus, on which no nutritional data are available, to the best of our knowledge.

Many of the wild plant collected may be considered as good vegetable sources of important mineral elements as calcium, magnesium and zinc, besides to have a low sodium-potassium ratio.

In addition, all plants had a low caloric content, and mostly of them a good total phenols content, especially the vegetative shoots apices of Rubus ulmifolius.

Anyway, the wild plants here analysed showed contents of nutrition values and total phenols differently distributed among them. Hence, they are useful for preparing mixed soups or salads in order to gain a balanced nourishment also for sodium content.

Therefore, a diversified diet based on traditional local herbs, also combining them with legumes, as in many soups is done, could be encourage the preservation of cultural heritage by providing an important and balanced nutraceutical source, appropriate especially in a vegetarian and vegan diet.

Finally, the information of this study, also by comparing our data with literature ones, support the opportunity to assess wild plants collected in natural environments, with appropriate agronomic techniques, as fresh-cut leafy vegetables of high nutraceutical value.

\section{References}

AOAC, 1995. Official Methods of Analysis, 16th ed. Association of Official Analytical Chemists, Arlington, VA, USA.

Bailey RL, Parker EA, Rhodes DG, Goldman JD, Clemens JC, Moshfegh AJ, Thuppal SV, Weaver CM, 2016. Estimating Sodium and Potassium Intakes and Their Ratio in the American Diet: Data from the 2011-2012 NHANES. J. Nutr. 146:745-50.

Benvenuti S, Maggini R, Pardossi A, 2017. Agronomic, Nutraceutical, and Organoleptic Performances of Wild Herbs of Ethnobotanical Tradition. Int. J. Veg. Sci. 23:270-81.

Bianco VV, Mariani R, Santamaria P, 2009. Piante spontanee nella cucina tradizionale molese. Levante Publishing, Bari, Italy.

Carnovale E, Marletta L, 2013. Tabelle di composizione degli alimenti. INRAN - Istituto Nazionale di Ricerca per gli Alimenti e la Nutrizione, Roma, Italy.

Carvalho AM, Barata AM, 2017. The Consumption of Wild Edible Plants. In: Ferreira I CFR, Morales P, Barros L (Eds.), Wild Plants, Mushrooms and Nuts: Functional Food Properties and Applications, 1st edn. John Wiley \& Sons, Ltd, pp 159-98.

Ceccanti C, Landi M, Benvenuti S, Pardossi A, Guidi L, 2018. Mediterranean Wild Edible Plants: Weeds or "New Functional Crops"? Molecules. 23:1-15.

Dhingra D, Mona M, Hradesh R, Patil RT, 2012. Dietary fibre in foods: a review. J. Food Sci. Technol. 49:255-66.

Di Novella R, Di Novella N, De Martino L, Mancini E, De Feo V, 2013. Traditional plant use in the National Park of Cilento and Vallo di Diano, Campania, Southern, Italy. J. Ethnopharmacol. 145:328-42.

Disciglio G, Tarantino A, Frabboni L, Gagliardi A, Giuliani MM, Tarantino E, Gatta G, 2017. Qualitative characterisation of cul- tivated and wild edible plants: Mineral elements, phenols content and antioxidant capacity. Ital. J. Agron. 12:383-94.

Drewnowski A, Maillot M, Rehm C, 2012. Reducing the sodiumpotassium ratio in the US diet: a challenge for public health. Am. J. Clin. Nutr. 96:439-44.

Ducci D, Tranfaglia G, 2008. Effects of climate change on groundwater resources in Campania (southern Italy). In: Dragoni W, Sukhija BS (eds.). Climate Change and Groundwater, Geological Society, London, Vol. 288, pp 25-38.

Fernandes L, Casal S, Pereira JA, Saraiva JA, Ramalhosa, E, 2017. E Edible flowers: A review of the nutritional, antioxidant, antimicrobial properties and effects on human health. J. Food Compos. Anal. 60:38-50.

Guil-Guerrero JL, 2001. Nutritional composition of Plantago species (P. Major L., P. Lanceolata L., and P. Media L.). Ecol. Food Nutr. 40:481-95.

Gupta UC, Gupta SC, 2014. Sources and deficiency diseases of mineral nutrients in human health and nutrition: a review. Pedosphere. 24:13-38.

Harris WS, Mozaffarian D, Rimm E, Kris-Etherton P, Rudel LL, Appel LJ, Engler MM, Engler MB, Sacks F, 2009. Omega-6 Fatty Acids and Risk for Cardiovascular Disease. Circulation. 119:902-7.

Marrelli M, Cristaldi B, Menichini F, Conforti F, 2015. Inhibitory effects of wild dietary plants on lipid peroxidation and on the proliferation of human cancer cells. Food Chem. Toxicol. 86:16-24.

Motti R, Motti P, 2017. An Ethnobotanical Survey of Useful Plants in the Agro Nocerino Sarnese (Campania, Southern Italy). Hum. Ecol. 45:865-78.

Pinela J, Carvalho AM, Ferreira ICFR, 2017. Wild edible plants: Nutritional and toxicological characteristics, retrieval strategies and importance for today's society. Food Chem. Toxicol. 110:165-88.

Poonia A, Upadhayay A, 2015. Chenopodium album Linn: review of nutritive value and biological properties. J. Food Sci. Technol. 52:3977-85.

Ranfa A, Maurizi A, Romano B, Bodesmo M, 2014. The importance of traditional uses and nutraceutical aspects of some edible wild plants in human nutrition: the case of Umbria (central Italy). Plant Biosyst. 148:297-306.

Regulation (EEC) 2568/91 of 11 July 1991 on the characteristics of olive oil and olive-residue oil and on the relevant methods of analysis. Off. J. Eur. Union. L248:36-47.

Regulation (EU) 1169/2011 of the European parliament and of the Council of 25 October 2011 on the provision of food information to consumers. Off. J. Eur. Union. L304:18-63.

Regulation (EU) 488/2014 of 12 May 2014. Off. J. Eur. Union. L138:75-79.

Regulation (EU) 2015/1005 of 25 June 2015. Off. J. Eur. Union. L161:9-13.

Regulation (EU) 2015/1833 of 12 October 2015. Off. J. Eur. Union. L266:35-44.

Renna M, 2017. Wild edible plants as a source of mineral elements in the daily diet. Prog. Nutr. 19:219-22.

Renna M, Cocozza C, Gonnella M, Abdelrahman H, Santamaria P, 2015. Elemental characterisation of wild edible plants from countryside and urban areas. Food Chem. 177:29-36.

Ruiz-Rodríguez BM, Sánchez-Moreno C, De Ancos B, SánchezMata M, Ruiz-Rodríguez V, Cámara M, Tardío J, 2014. Wild Arbutus unedo L. and Rubus ulmifolius Schott fruits are underutilised sources of valuable bioactive compounds with antioxidant capacity. Fruits. 69:435-48. 
Said AAH, El Otmani IS, Derfoufi S, Benmoussa, 2015. A Highlights on nutritional and therapeutic value of stinging nettle (Urtica dioica). Int. J. Pharm. Sci. 7:8-14.

Sánchez-Mata M, Tardío J, 2016. Mediterranean Wild Edible Plants, Ethnobotany and Food Composition Tables. Springer, New York, NY, USA.

Simopoulos AP, 2004. Omega-3 fatty acids and antioxidants in edible wild plants. Biol. Res. 37:263-77.

Targioni-Tozzetti G, 1767. De alimenta urgentia: Alimurgia, ossia modo per rendere meno gravi le carestie, proposto per il sollievo dei popoli. Firenze, Italy.
Turner NJ, Łuczaj LJ, Migliorini P, Pieroni A, Dreon AL, Sacchetti LE, Paoletti MG, 2011. Edible and Tended Wild Plants, Traditional Ecological Knowledge and Agroecology. Crit. Rev. Plant Sci. 30:198-225.

Ulewicz-Magulska B, Wesolowski M, 2019. Total Phenolic Contents and Antioxidant Potential of Herbs Used for Medical and Culinary Purposes. Plant Foods Hum. Nutr. 74:61-7.

Vanzani P, Rossetto M, De Marco V, Sacchetti LE, Paoletti MG, Rigo A, 2011. Wild Mediterranean Plants as Traditional Food: A Valuable Source of Antioxidants. J. Food Sci. 76:C46-51. 